\title{
Cave Tourism and its Implications to Tourism Development in Nigeria: A Case Study of Agu-Owuru Cave in Ezeagu
}

\author{
Emeka E. Okonkwo', Ezekaka Afoma², Igwemadu Martha ${ }^{3}$ \\ ${ }^{1,2,3}$ Department of Archaeology and Tourism, University of Nigeria, Nsukka
}

\begin{abstract}
Caves are natural resources that are valued to tourists because of its inherent natural features. This form of tourism attractions are being developed around the world primarily as a tool for the development of local and regional communities for income generation. Tourists are motivated to visit caves for adventures, education/research, socialization, recreation, and scientific purposes. Caves are very important to tourism if properly harnessed as it will improve the social and economic well being of the host community and also in conservation of the biodiversity and the environment. This paper examines the implication of cave to geotourism development in Nigeria with emphasis on Agu-Owuru cave in Ezeagu. The study uses ethnographic research method to elicit useful data and analyse them descriptively. Through the use of SWOT analysis, the paper proffers sustainable way of harnessing Agu-Owuru cave for geotourism development. The paper argues that if the studied cave is developed for tourism purposes, it will create job opportunities, improve the living standard of host community, and create avenues where economic goods will be captured as well as infrastructural development.
\end{abstract}

Keywords: Cave, tourism, development, geotourism and implications

\section{INTRODUCTION}

Cave tourism is becoming increasingly important to tourism development and as such tourists are motivated to visit cave for its inherent natural landscape features. Caves are part of nature or ecotourism that is capable of attracting tourists from different part of the world (Rindam, 2014). These natural landscapes are found fascinating and valuable to tourists. Caves constitute key elements of a karst system intervening through transformation process in the surface and subsurface of the physical environment and harbouring of wildlife (Lobo and Moretti, 2009). Tourist visit caves for recreation, education, and sometimes adventure reasons and People who explore caves often wear battery power headlamps and sometimes torch lights. In Nigeria, we have so many caves that have rich potentials for tourism development but are still lying dormant or untapped. Most of these caves are found in south eastern Nigeria. For example, Ogbunike cave, Owerri-Ezukala cave, Obimo cave, Uturu cave, Opi cave, Ajalli cave, Ugwuelle cave, Agu-Owuru cave etc. However, most of these cave have been relegated to the background without tourism consideration (Oguamanam \& Nwankwo, 2015).

Caves as natural resources can be great potential for tourism development and in return increase the growth of the economy of its host residents (Rindam, 2014) as well as help the government to achieve environmental awareness and environmental control education. Itanyi, Okonkwo and Eyisi (2013) opine that caves and rock-shelters have an immense value to both archaeologists and tourism operators. For archaeologists they provide information on habitation pattern of past human occupants including their dietary habits and religious belief system, while tourism operators and tourists perceive caves and rock-shelters as a means of experiencing nature based tourism or ecotourism. According to Knezevic and Zikovic (2011) caves are endowed with morphological features valuable for tourism development and with special interest to adventure tourists.

Caves are important to tourism industry if properly harnessed and developed as it will rapidly increase economic, social and environmental benefits to the host community. Generally, tourism development often has both positives and negative implications on the host community. These are grouped into economic, socio-cultural and environmental implications which occur through interactions between host community and tourist during tourism experience or encounter. Tourism as a commercial activity can bring about economic, social, and environmental changes to tourism destination. 
Agu-Owuru cave has a scenic landscape and awe-inspiring for tourist consumption. The cave development will promote and enhance the economic wellbeing of the host community as well as create a means of environmental conservation of the environment. These potentials as much as they look have been advanced by research works. However, none of the recommendations of the previous research works has be strictly implemented either as a result of mere negligence or lack of detailed economic and environmental gains such potentials hold for the host community and the government. The paper aims to explore the implications of Agu-Owuru cave to cave tourism development and how these implications will be maximized to equal benefits to all concerned in tourism development. Cave as tourist destination has some of the geologic features that had become the object of tourism (Eva and Sunkar, 2013); hence, this paper tends to study the implications of Agu-Owuru cave to tourism development and for tourism developers to maximize the implications performances accruable to tourism development. The study will promote caves as means of economic development and environmental conservation.

\section{METHOD OF RESEARCH}

Ethnographic research method was used to prosecute the study. However instruments of data collection used in the course of the research are submerged under primary and secondary sources of data collection. Data collected from the primary sources were mainly in-depth interviews, oral tradition and key informants interviews. The secondary sources of information include textbooks, journals, internet materials, conference papers and unpublished materials. Information obtained from both primary and secondary sources were used in the analysis and interpretations of our findings.

\section{THE STUDY AREA}

Ezeagu is one of the local government in Enugu State, Nigeria and it is located at about 9 kilometres south west in central part of the state, geographically referenced at coordinate $6025^{\prime} \mathrm{N} 7015^{\circ} \mathrm{E} / 6.4170$ $\mathrm{N} 7.2500 \mathrm{E} / 6 / 417$, with land mass of over 626 kilometres and population of about 169,718 people at 2006 census (www.wikipedia.com) . The Ezeagu Tourist Complex is geographically located within Obinofia Ndi-nuo and Omughu Obeleagu Umuna all in Mbanito sub-region of Ezeagu. The tourist complex lies with equatorial zone of the forest region geographically referenced about 15 'north of the equator and 18' east of the green meridian. The complex is bounded in the east by Nachi in Udi local government.

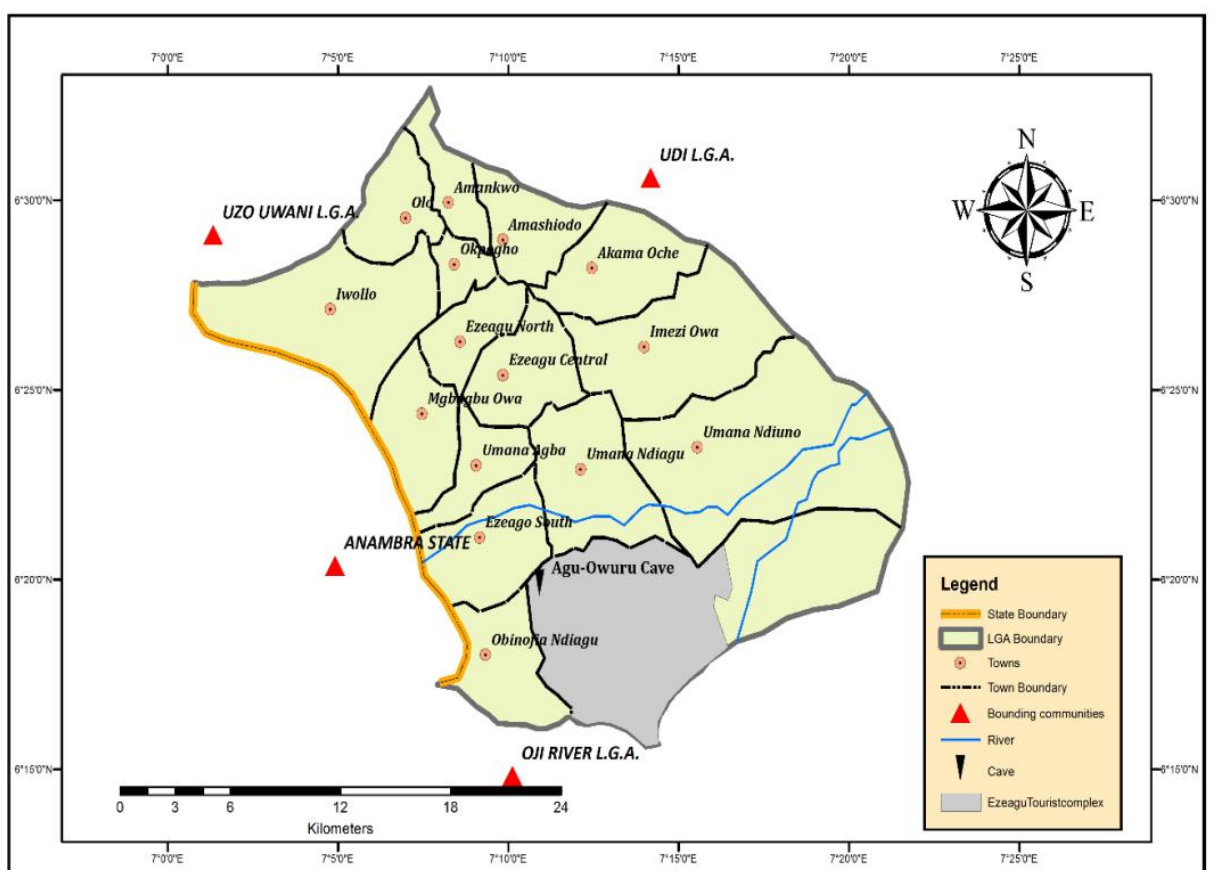

Figure1. Map of Ezeagu Showing Agu-Owuru Cave

\section{An Over View of Agu-OWuru Cave}

The geographical location and the atmosphere within which the study area exist can be a source of attraction to some Nigerians who would have to travel across different land and cultures. Such natural 
Cave Tourism and its Implications to Tourism Development in Nigeria: A Case Study of If there are images in this attachment, they will not be displayed. Download the original attachment

areas if encouraged can widen national horizon and instil deep sense of appreciation of our natural and cultural varieties and a sense of pride in belonging to a country so big and diverse.

According to our informant, Mr. Benjamin Iruama, $O g b a$ is known as cave in Igbo language. $O g b a$ Agu-Owuru (Agu-Owuru cave) derives its name from the belief that lion $(A g u)$ lived in the cave in the olden days. That is how the name Agu-Owuru cave was derived (meaning: a cave that inhabits lion).

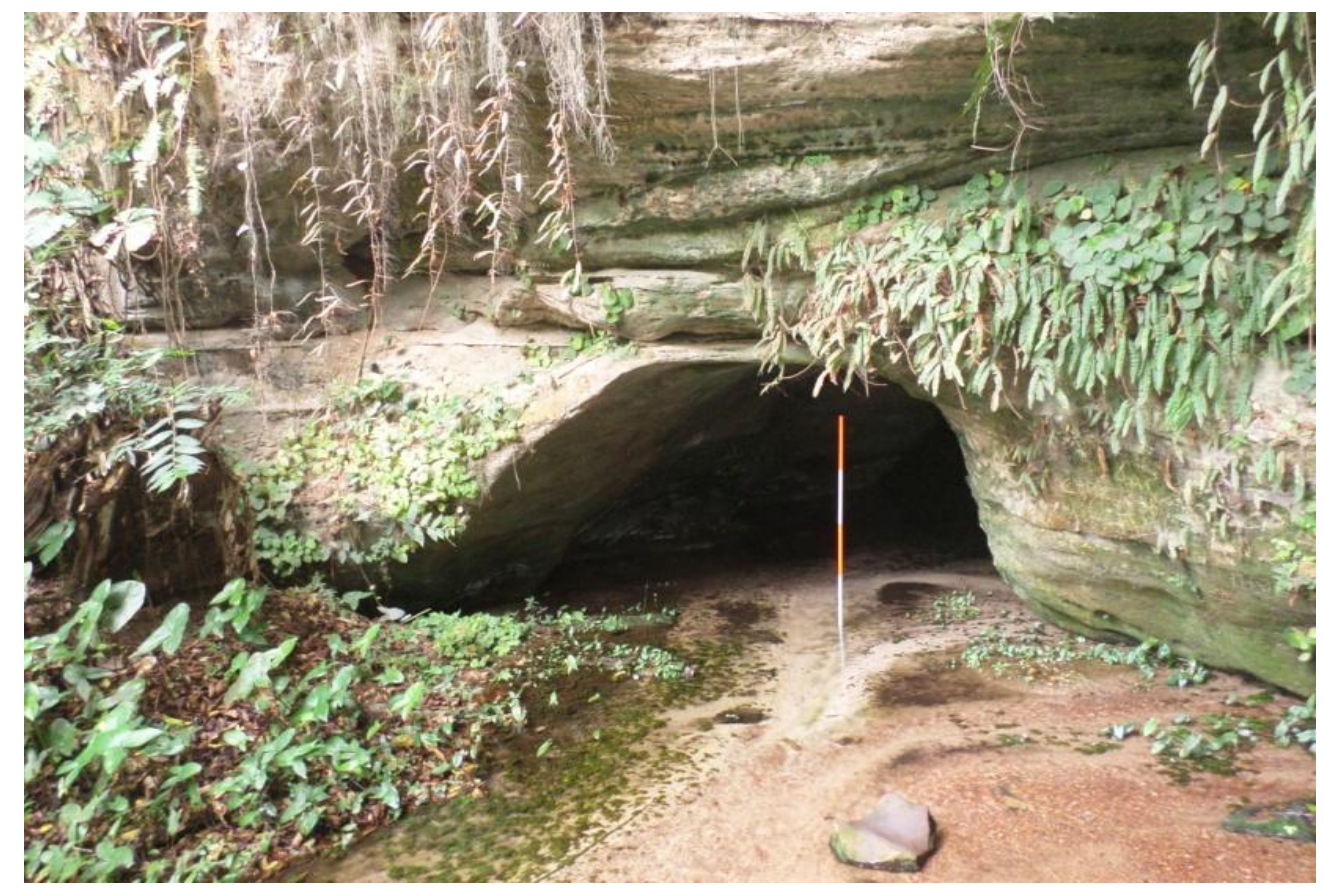

Plate1. The Entrance of the Agu-Owuru Cave

Ethnographic sources revealed that during the civil war, the cave serves as a hiding place for the community and that the length of the cave could reach $9^{\text {th }}$ Mile in Enugu state, which is not yet confirmed. The origin of the cave is unknown among the people of Ihuezi clan; however a single date of about 3,000 years has been given by Enugu State Tourism Board (www.enugustatetourism.com). This date has not been proven by any scientific evidence(s) through historical, archaeological and anthropological investigations. The cave also host a deity called "Ogba". This is where religious activities are been carried out by its adherents. Also, in the olden days most celebrations are held in the shrine. Such celebrations include new yam festival, family celebrations and other community festivals. The deity also plays a role of purification, consultation and appeasing and sacrifices are performed at the deity for whatsoever reasons. The deity is located close to the cave. The deity serve as a demarcation of those who are frees from the laws and taboos of the cave. This laws and taboo includes:

1. A woman observing her menstruation is not allowed to enter the cave

2. A woman still mourning her husband is not allowed to enter the cave

3. A woman who commit abortion within a year is not allowed to enter the cave

4. A woman on pants/trousers are not allowed to enter the cave

5. Hunting of games is allowed at the cave but the hunter must roast, prepare and eat a portion of the meat in front of the cave before taking the rest home.

The items found in the shrine of $O g b a$ deity were old pair of shoes, a stainless plate with $35 \mathrm{cl}$ CocaCola can drink placed on it which are believed to be a sacrificial items. The road to the cave is through a thick swampy forest. There are two entrances to the cave with three chambers. The major entrance measures about $2.5 \mathrm{~m}$ in height and $3.7 \mathrm{~m}$ in width. While the second entrance measures 2.8 meters in height and 1.9 meters width. The first and the largest chambers are 2,960 meters and 13.2 meters high. The satellite location is North 6.31052 and East 7.26732 and the cave is located at 310 North West of Ihuezi villages. There is presence of small games like bats, python, snakes etc but are 
not harmful to the visitors who abide to the rules and regulations of the cave as affirmed by our informants. The bats are the visible animals in the cave, immediately they hear the sounds of human being inside the cave, they take to their flights producing shrill sounds. Some of these bats are seen in the entrance of the cave. The cave also has a stream called Onuogba stream that flows out of it which serves as a source of water to the community. There are also openings at the top of the cave called shallow holes from where sun rays lighten the cave. The second chamber is like a corridor that links the first and the third chambers. It measures $22 \mathrm{sq} . \mathrm{km}$ with a height of 2.6 meters. The chambers are very dark and it links the major entrance to the third chamber. The third chamber which measures 18 sqkm is the darkest of all the chambers and visibility is often difficult even with a torch light. It is believed to be a place where spirit resides.

The cave has religious and traditional significances to the community. The shrine is worshiped by the community and has a festival celebrated in its honour and it is called Oku Onuogba. It is celebrated annually in the month of April. During the festival, local dishes such as pounded yam and roasted yam are prepared and sacrificed to the shrine. Ethnographic sources trace the history of the festival to a child that was believed to reincarnate from the shrine. An oracle was consulted upon the child's birth; this was followed by winning and feasting at the shrine with the family of the child and other invited people offering sacrifices and thanks to the shrine. According to our informants, the shrine currently does not have a priest that performs ritual or act as a custodian between the deity and the people because the former priest is now a Christian.

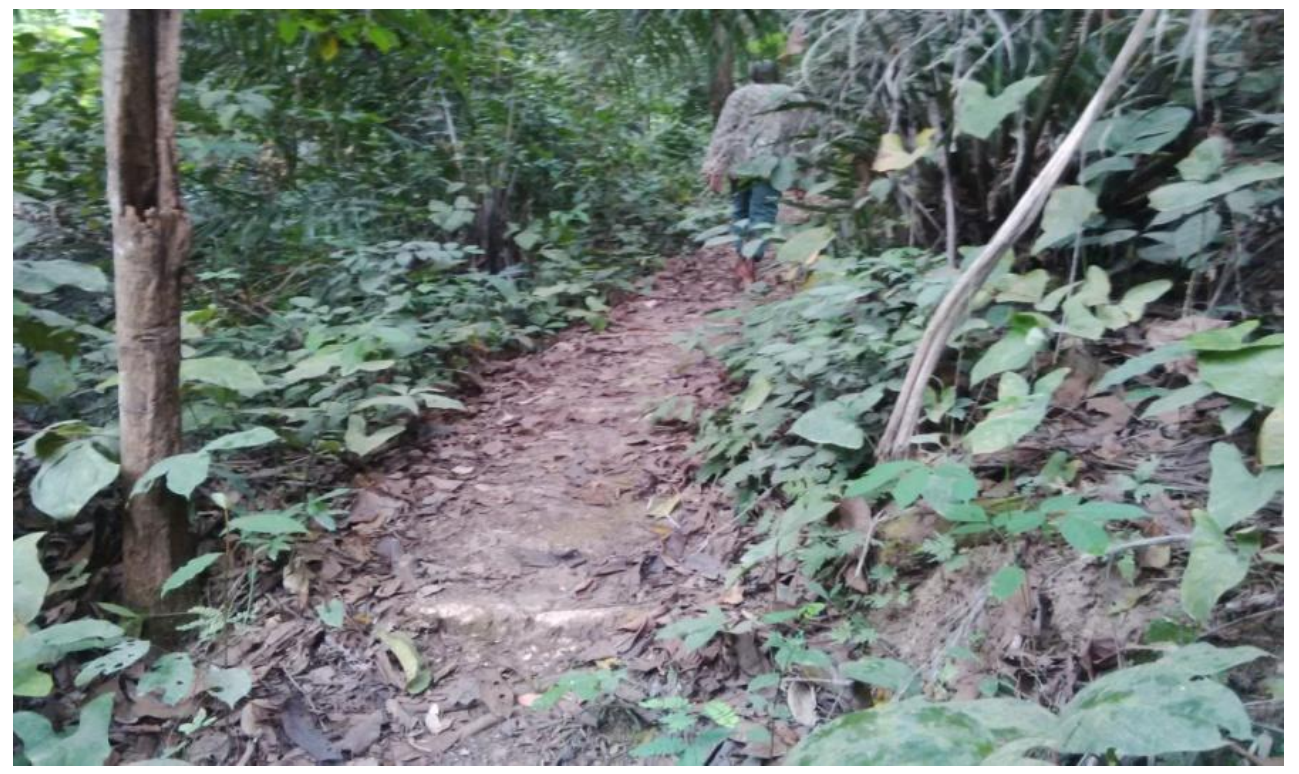

Plate2. Pathway to the Cave

\section{Harnessing Agu-OWuru Cave for Cave Tourism Development}

Cave tourism is tourism that sustains or enhances the geographical character of a place its environment, heritage, aesthetics, culture, and the wellbeing of its residents (National Geography Society, 2002). This means that cave tourism is a multifaceted form of tourism ranging from natural areas, historical attributes of a place, archaeological sites, scenic landscapes, traditional architecture, local cuisine, music, arts and dance. At the same time, it is a tourism that conserves the environment and enriches the economy of a place.

Agu-Owuru cave also have good geotourism attributes with unique geological features that can attract tourists and at the same time sustain the environment, cultural heritage and the well being of the residents if properly harnessed for tourism development. The local residents have also seen the potentials of the cave for development as the community youths manages the site and offer it to the public as tourism product. This shows their concern in the economy and social development of the area which can be seen as an opportunity to develop the cave for tourism purposes.

For this reason, a strategy for harnessing Agu-Owuru cave for tourism development is illustrated in the table below: 
Cave Tourism and its Implications to Tourism Development in Nigeria: A Case Study of If there are images in this attachment, they will not be displayed. Download the original attachment

Table1. Strategy for Harnessing Ag- Owuru Cave Based on SWOT Analysis

\begin{tabular}{|l|l|}
\hline $\begin{array}{l}\text { Harnessing the Strength (S) of the Cave for } \\
\text { Tourism Development }\end{array}$ & $\begin{array}{l}\text { Harnessing the Weakness (W) of the Cave for } \\
\text { Tourism Development }\end{array}$ \\
\hline $\begin{array}{l}\text { 1) Identify the current condition of the cave and its } \\
\text { features. }\end{array}$ & $\begin{array}{l}\text { 1) Improving the understanding of the community } \\
\text { about geotourism development }\end{array}$ \\
\hline $\begin{array}{l}\text { 2) Documenting and publishing the features of the } \\
\text { cave and its scientific value. }\end{array}$ & $\begin{array}{l}\text { 2) Formulating a geotourism management plan in } \\
\text { accordance with geotourism concept. }\end{array}$ \\
\hline $\begin{array}{l}\text { 3) To formulate geotourism plan development in a } \\
\text { manner that both tourism and geological } \\
\text { stakeholders must work towards a common goal of } \\
\text { conservation enriching tourism experience. }\end{array}$ & $\begin{array}{l}\text { 3) Planning of marketing and promotion of geotourism } \\
\text { to the public. }\end{array}$ \\
\hline $\begin{array}{l}\text { 4) provide geotourism management model that will } \\
\text { include community participation. }\end{array}$ & $\begin{array}{l}\text { 4) Improvement of social amenities and tourism } \\
\text { facilities. }\end{array}$ \\
\hline $\begin{array}{l}\text { Harnessing the Opportunity (O) of the Cave for } \\
\text { and implementation. }\end{array}$ & $\begin{array}{l}\text { Harnessing the Threat (T) of the Cave for Tourism } \\
\text { Development }\end{array}$ \\
\hline $\begin{array}{l}\text { 1) To increase the understanding environmental } \\
\text { preservation and conservation to the local residents } \\
\text { and the public in general. }\end{array}$ & $\begin{array}{l}\text { 1) Creating awareness to the community or } \\
\text { importance of environmental conservation. }\end{array}$ \\
\hline $\begin{array}{l}\text { 2) Provision of conservation plan } \\
\text { 3) Developing diversification in responding to } \\
\text { geodiversity. }\end{array}$ & $\begin{array}{l}\text { 2) Making provision of conservation and preservation } \\
\text { mechanism for the present and future generation. }\end{array}$ \\
\hline
\end{tabular}

The various strength (S) will help to sustain and promote the cave for conservation of the protected area, which will lead to successful tourism development and management practices and also would help to plan tourism in a manner that both geological and tourism stakeholders should work together in other to achieve common goal. As posited by Hose and Vasiljevic (2012) cave tourism development provisions should be planned in a way that both tourism and geological stakeholders must work towards common agreed aims and objectives, otherwise sustainable tourism development will not be achieved. Having examined the current state of the cave which has tourism value to serve as tourist attraction, it should be documented and published for its features contain therein. This will improve economic benefits to the community and increase number of visitation.

The threats (T) includes restoration of damaged features such as lost colour of the stalactites within the cave which shows signs of dryness and mould, creating community awareness for preservation and conservation of the site for present and future generation. The tourism stakeholders and State Tourism Board will aid in the restoration and conservation of the environment. The weakness (W) entails making the community to understand the importance of tourism in environmental conservation through direct economy benefit from tourist who pay some amount of money to visit the destination, with this the destination is made clean and preserved. There is also need to formulate tourism plan in marketing and promoting the cave to the public. This can be achieved through the various forms of advertisement like brochures, newspapers, tourism newsletters etc. This will draw attention of tourists to the destination.

The cave should also be made accessible through all forms of transportation; while, social amenities/tourism facilities such as communication network, pipe borne water, electricity etc should be provided to attract tourists to the destination. This will be achieved through government collaboration with the private sectors. The opportunity $(\mathrm{O})$ implies the provision of plan for tourism development and conservation that will constitute community destination enhancement, economic needs and adoption of strategies that will minimize the socio-cultural impacts and boast the destination image.

The model was used to assess the strength of potential tourism attraction for tourism development using 13 geo-sites in Gununngkidul Regency, Indonesia. Before the initiation of the model for the development of the sites for tourism development, the site has its own unique features that attract tourists to the destination which the community are aware of and has benefited from it. The SWOT 
model has succeeded in reducing the threats accrue to tourism development especially socio-cultural aspects for instance reaching harmony and balance of living environment for both host residents and tourist in the destination and it has also helped in planning and managing a sustainable tourism development aimed at conservation of the environment and to enhance community participation in tourism management. It has also brought economic benefits to the community and local government. The researchers has no doubt that if SWOT is also used in planning and developing cave tourism in Ezeagu as proposed in this research report, it will record huge success.

\section{Implications of Agu OWURU Cave to Tourism Development}

The implications of Agu-Owuru cave cannot be over emphasized. This ranges from economic to socio-cultural implications. Tourism is an industry with enormous economic, socio-cultural and environmental implications. Tourism like any other industry is often used as a national or regional development tool. In general, tourism development within a community often has implications on the community both positive and negative ways. These implications have been well documented and are classified as economic, socio-cultural, and environmental implications. For this reason, the implications of Agu-Owuru cave to tourism development will be discussed.

Agu-Owuru cave tourism development will alter the economic structure of the community and will be a major source of capital and income to the local people if the cave is properly planned, developed, and managed. Cave tourism development can create job opportunities, earn foreign exchange, produce return on investment for emerging economics, bring infrastructural development and improve living standard of the locals. Tourism can also help to increase revenue generation of the local people and will creation employment opportunities.

The socio-cultural implications of Agu-Owuru cave for tourism development are the effects of tourism to the host communities through interactions during tourism experience and encounter. These interactions will bring changes to the quality of life of the residents such as their belief system, traditional lifestyle, family relationships, religion etc. As posited by Kadt (1979 as cited in Blacstock, 2015) tourist and host contacts takes place in three general contexts: places where tourists purchase goods and services from the hosts, places where they are using or occupying at the same time and lastly places in which they meet and share knowledge and ideas. Tourism socio-cultural implications will be identified as both positive and negative.

The positive socio- cultural implications includes promotion of cross-cultural understanding, social transformation, increase in standard of living, development of infrastructural facilities, provisions of goods and services and social stability. Cave tourism development can also bring about preservation and conservation of historical buildings, archaeological sites and the environment. This can be achieved through the collections of entrance fees, souvenir sales, sales of local cuisines, local tour guide fees and so on.

The negative socio-cultural implications associated with tourism activities includes demonstrative effect whereby tourist behaviour at destination influences the host communities especially the young ones. The host community tends to imitate tourists way of life and abandoning their traditional way of life and viewing it as inferior. Another negative impact of tourism is commodification of culture to suit tourist markets which might also alters the original cultural practices and patterns thereby losing its original significance.

Finally, the environmental implications of Agu-Owuru cave to tourism development include conservation and protection of the natural environment. Scenic settings of the cave is a desirable assets for attracting tourist and also for archaeological purposes as it serve as a source of information about past human activity such as changes in vegetation, habitation sites, and also believed to preserve the cultural sequence of human occupation that make use of the cave at one point in time (Itanyi et. al. 2013).

Environmental implications of Agu-Owuru cave also include environmental restoration of biological diversity and sustainable use of natural resources in the area; it will also increase public appreciation of the environment and to spread awareness of environmental issues as it brings people into closer contact with nature and environment, hence it will widen the horizon of the people on the need for environmental conscious behaviour and activities to preserve the environment and also reduce resource degradation 
Congestions experienced at tourism destination increase the demand for natural resources and also contributes source of solid waste residual that causes pollution. Land degradation through construction of accommodation facilities, parking space and recreational facilities cannot be overlooked. Tourism activities also generate waste products at destination as tourists' litters the environment with used materials such as waste bags, toilet papers, food bags and so on.

\section{DISCUSSION}

Sustainable tourism development as anchored on the United Nations World Tourism Organization Global Code of Ethics for Tourism Article I, emphasize on the need for tourism development to foster the attitude of tolerance and respect of religious, philosophical, and moral beliefs diversity among participants (Edgell et al, 2008 cited in Misiko, 2015) as such tourism developers and all stakeholders should put into consideration social values of the host community and respect their indigenous practices during tourism activities. In the case of Agu-Owuru cave, the tourism developers and all interested individuals in tourism development should ensure that all traditional practices associated with the cave should be respected and strictly adhered to for sustainable tourism development.

According to one of our key informants, most times the tourist disrespect the cultural belief system attached to the cave such as visiting the cave during menstruation. At this junction, the tourism developers should make effort to plan and provide adequate provisions for sensitizing and creating awareness to the public concerning the indigenous practices associated with the cave. For instance, mounting a sign post in front of the road leading to the cave specifying various taboos associated with the cave would help to avert the impending danger that is associated with disrespecting the local norms and traditions.

The economic implications are focused on the revenue/income generated from the site. The main direct tourism income from Agu-Owuru cave is the tollgate. The youths are also responsible for the maintenance of the site and act as tour guides. The money that is generated from the tollgate is used in maintaining the site as well as for the welfare of the community members. However, the revenue generated from the site is not enough for the maintenance of the site. It is also noticed that most tourists visit the site with their food items such as snacks, drinks etc, thus, resulting to low patronage of petty traders' locally made snacks and drinks. This can be minimized if tourism developers together with stakeholders will provide shopping facilities within the destination so that tourists will patronize from them rather than bringing those food items from outside. In developing the cave, emphasis should also be laid on equipping the tourist guides with good communication skills. In the course of our research, it was observed that the local tour guides speaks their indigenous dialect rather than English. This poses serious challenge to most tourists, thus, the need to train them on communication skills in other to improve their skills.

Other indirect sources of revenue include money paid by tourists to motor cyclists and vehicles for conveying them to the site as well souvenirs. This income contributes to the local economy of the host community. Generally, the income generated from the destination is limited because of the fact that the site is not yet fully developed and the management plan is very poor.

The environmental implications focus on the environmental management of the site. One of the major environmental challenges facing the site is littering of waste product by tourists. Erosion has also caused damage to the pathways leading to the cave. This explains why tourism developers and the community should plan tourism in order to manage the environmental issues and also create awareness in conservation and preservation of the environment.

Considering the level of tourism development in Ezeagu which is still at its lower stage, there is need for synergy between tourism professionals, government and host community in other to have sustainable development of cave tourism in Ezeagu. Such synergy will help to bring together all the complementary factors in tourism development and promotion, which will help to strengthen and reposition the cave proper for tourism development in Ezeagu which the area could not ordinary achieve on its own. The complementary factors will also help to manage the implications accrue to tourism development and to generate maximum benefits to host community, tourists and investors while minimizing its negative effects. 
For a well planned tourism development and management of tourism implications to succeed, critical studies should be done on these natural resources by Enugu State Tourism Board to determine its market potentials and the perception of host community on implications of tourism development. The essential aim is to identify current and potential visitors, where they are coming from, what they want, how much they can pay etc, so as to package the product to meet their needs and also the perceived economic impacts. The Enugu State Government should involve the local and private sectors and nongovernmental organization in this evaluation process to determine the market potentials and quality customers. Such a study should include survey of visitor satisfaction, measurement of economic benefits to local community as well as environmental/social cultural impact assessment of the proposed tourism development to host community.

Infrastructure is the bedrock of any meaningful tourism development, hence government should provide basic infrastructure to cater for the inflow of visitors e.g. access road to the attraction sites, provision of electricity, communication networks, good water supply etc. In the process of this development, the government should also work in collaboration with private sectors in providing superstructures such as accommodation and transportation services, souvenir shops, etc for tourist satisfaction.

Furthermore, there should be establishment of sound institutional framework like the Local Government Tourism Committee (LGTC), State Tourism Board (STB) etc that will make policies for the management of the destination site. It should be noted that Section 10 of Decree No 81 of 1992 provide for the establishment of Local Government Tourism Committee (LGTC) in each local government area of the federation. Part of the LGTC role is to recommend potential tourism projects to the State Tourism Board for development. However, suffice it to state here that LGTC policy is not implemented. Thus, Nigeria Tourism Development Corporation should ensure that LGTCs are instituted at local government levels in other to achieve their objectives for which Decree No 81 of 1992 was promulgated. Publicity and promotion is another important aspect in tourism development. The attractions should draw the attention of potential/quality customers. This can be achieved through adverts on television, radio, billboard, brochures etc.

Moreover, the local community should be educated on how to present tourist product to visitors. The local residents should also be involved in the planning process and development of tourism destination site as it appears to be desirable and necessary element of sustainable tourism development especially in the case of community-based tourism development.

\section{Conclusion}

Agu-Owuru cave tourism will benefit local communities and lead to their development if properly harnessed and developed. It requires both human and material resources. Ezeagu is blessed with abundant tourism sites that can attract both domestic and foreign tourists. This can help to achieve substantial revenue growth for the local communities and at the same time aid in the preservation and conservation of natural areas. For tourism in Ezeagu to have its fair share of the global market and maintain visitor arrival, there is the need to invest heavily on its development especially the areas of infrastructure and promotion of the tourist sites which are the important target market and also manage the implications arising from tourism development.

This paper has outlined the implication of cave to tourism development and how these implications can be maximized to equal benefits to all concerned in tourism development. It also identified how the cave should be harnessed for cave tourism development based on SWOT analysis, which pointed out the roles of relevant stakeholders towards effective planning and management of cave tourism.

\section{REFERENCES}

[1] Blackstock, K. (2005). A critical look at community-based tourism. Community Development Journal. Vol. 40, No. 1. Retrieved from http://www.researchgate.net/publication/31505718 Accessed on 21/5/2016.

[2] Eva, R. \& Sunkar, A. (2013). Consumer based cave travel and tourism market characteristics in West Java, Indonesia. Campinas. (Online) SEtur/SEB. Tourism and Karst Areas, Vol. 6 (1), 2013. Retrieved from http://www.carernas.or.br/../tka_vb_n1_057... Accessed on 12/6/2016.

[3] Eze-Uzomaka, P.I. (2006). Tourism and community development. In Okpoko P.U (Ed.), Issues in Tourism Planning and Development. Nsukka: Afro-Orbis Publication. 
Cave Tourism and its Implications to Tourism Development in Nigeria: A Case Study of If there are images in this attachment, they will not be displayed. Download the original attachment

[4] WIKIPEDIA. Ezeagu. Retrieved from https;//en.mwikipedia.org/wiki/Ezeagu. Accessed on 20/6/2016

[5] Ezeani,J. (n.d). Impact of tourism in Ezeagu Local Government Area of Enugu State. Retrieved from enugustatetourismboard.com/p.php?.. Accessed on 16/4/2016.

[6] Hose, A.T. \& Vasiljevic, D. (2012). Defining the nature and purpose of modern geotourism with particular reference to the United Kingdom And South-East. (Online) Article of Geo-heritage. Retrieved from http://www.researchgate.net/publication/257763510 . Accessed on 20/11/2016.

[7] Igbo, E. U. M. and Okpoko P. U. (2006). Theoretical consideration in tourism planning and development. In Okpoko P. U. (Ed.) Issues in Tourism Planning \& Development, (pp. 16-23). Afro-orbit Publishing Co. Ltd Nsukka.

[8] Itanyi, E.I., Okonkwo, E.E \& Eyisi, A.O. (2013). A preliminary study of cave, rock-shelters and waterfalls in Owerre-Ezukala, Orumba South Local Government Area of Anambra State, Nigeria. (Online) Journal of Tourism and Heritage Studies, Vol.2, No.1. Retrieved from www.atdin.org/download.php?...file... Accessed on 12/6/2016

[9] Knezevic, R. \& Zikovic, R.G. (2016). Analysis of the condition and development opportunities of cave tourism in Primorsko Goranska Country. (Online) Turizam Journal. Vol. 15. Retrieved from www.dgt.uns.ac.rs/.../vol_1501_kenezevic... Accessed on 12/6/2016.

[10] Lobo, H.A. \& Moretti, E.C. (2009). Tourism in caves and the conservation of the speleological heritage: The case of Serrada Bodoquena (Mato Gross Do Sul State, Brazil). (Online). Retrieved from oj.zrc.sazu.si/carsological/article/.../127. Accessed on 12/6/2016.

[11] Marlina, E. (2016). Geotourism as a strategy for geosite empowerment towards the tourism sustainability in Gunungkidul Regency, Indonesia.(Online) Journal of Smart Home, Vol.10.5 pp 131-148. Retrieved from http://dx.doi.org/10.14257/ijsh.2016.10.5.13 Accessed on 13/11/2016.

[12] Misiko, A.J. (2015). Impacts of development process on Mawanga cave tourism sustainability: lessons for future improvement. (Online) International Journal of Arts and Commerce. Vol.4 No.4. Retrieved from www.ijac.org.uk. Accessed on 12/8/2016.

[13] National Geography Society (2002) Geotourism highlights. Retrieved from www.nationalgeography.com/geosurvey/... Accessed on 12/6/2016.

[14] Oguamanan, C.C. \& Nwankwo, E.A (2015). Sustainable development plans for caves in southeast Nigeria for tourism. (Online) Journal of Tourism, Hospitality and Sports, Vol 3. Retrieved from www.iiste.org/Journal/index.../17757. Accessed on 12/5/2016.

[15] Okpoko P. U. \& Ezeh P.J. (2005). Method in Qualitative Research. Nsukka: Great Ap Express Publishers Ltd

[16] Okpoko, A. I. \& Okpoko P. U. (2002), Tourism in Nigeria. Afro-Orbis Publication Ltd Nsukka

[17] Rindam, M. (2014). Cave Tourism: The Potentials of Ascar Cave as a Natural Tourism Asset At Lenggong Valley, Perak. (Online) SHS of Conferences Centre for Distance Education, University Sains Malaysia. Retrieved from http://www.shs.conferences.org. Accessed on12/6/2016

Citation: Emeka E., Okonkwo et al. "Cave Tourism and its Implications to Tourism Development in Nigeria: A Case Study of Agu-Owuru Cave in Ezeagu." International Journal of Research in Tourism and Hospitality (IJRTH), vol 3, no. 3, 2017, pp. 16-24. doi:http://dx.doi.org/10.20431/2455-0043.0303003.

Copyright: (C) 2017 Authors. This is an open-access article distributed under the terms of the Creative Commons Attribution License, which permits unrestricted use, distribution, and reproduction in any medium, provided the original author and source are credited. 